\title{
Stable Carbon Isotope Stratigraphy of the Cambrian Machari Formation in the Yeongweol Area, Gangweon Province, Korea
}

\author{
Gong Soo Chung ${ }^{1, *}$, Jeong Gu Lee ${ }^{2}$, and Kwang Sik Lee ${ }^{3}$ \\ 'Department of Geology and Earth Environmental Sciences, Chungnam National University, \\ Daejeon 305-764, Korea \\ ${ }^{2}$ Exhibition Planning and Coordination Division, Gwacheon National Science Museum, \\ Gwacheon, Gyeonggi 427-060, Korea \\ ${ }^{3}$ Division of Earth and Environmental Science, Korea Basic Science Institute, \\ Ochang, Chungbuk 363-883, Korea
}

\begin{abstract}
The Steptoean Positive Carbon Isotope Excursion (SPICE) is found in the Machari Formation which was interpreted to have been deposited on the middle to outer carbonate ramp environment. The Machari Formation is the Middle to Late Cambrian in age and distributed in the Yeongweol area, Gangweon Province, Korea. The SPICE event in the Machari Formation begins with the first appearance datum of trilobite Glyptagnostus reticulatus and ends with the first appearance of datum of trilobite Irvingella. The SPICE is found in approximately $120 \mathrm{~m}$ thick sequence and $\delta^{13} \mathrm{C}$ values in the SPICE interval range from 0.6 to $4.4 \%$. The SPICE in the Machari Formation is interpreted to be caused by burial of organic matter in the sea floor and subsequent increase of ${ }^{13} \mathrm{C}$ isotope of the Late Cambrian ocean. The SPICE interval in the Machari Formation corresponds to the highstand to transgressive systems tracts.
\end{abstract}

Keywords: SPICE, Machari Formation, carbonate ramp, sequence stratigraphy

\section{Introduction}

Stable carbon isotopes have been used for global stratigraphic correlation of Cambrian strata. Chemostratigraphy of high-resolution carbon isotope records during Steptoean, known as the SPICE (Steptoean Positive Carbon Isotope Excursion), is a powerful stratigraphic tool to correlate continents (Saltzman et al., 2000, 2004; Zhu et al., 2004; Ahlberg et al., 2009). The SPICE represents up to $4-6 \%$ shift in $\delta{ }^{13} \mathrm{C}$ values in Late Cambrian successions; it started 499 Ma and lasted 2-4 million years (Gill et al., 2011). The base of the Glyptagnostus reticulatus Zone defines the base of the Paibian Stage and Furongian Series (Zhu et al., 2004) and the first appearance datum (FAD) of trilobite G. reticulatus coincides with the onset of SPICE (Peng et al., 2004). The peak values of the SPICE occur between the FADs of $G$. reticulatus and Irvingella. The onset and the

\footnotetext{
*Corresponding author: gschung@cnu.ac.kr

Tel: +82-42-821-6429

Fax: $+82-42-822-8733$
}

stratigraphic age of the peak values of the SPICE seem to be diachronous and vary between regions (Ahlberg et al., 2009). Hence, the peak values of the SPICE vary significantly between regions. The discrepancies in onset and peak values of the SPICE could be caused by uncertainties in biostratigraphic resolution (Saltzman et al., 2000) and inconsistency in sampling technique (Ahlberg et al., 2009).

The SPICE indicates transient increases in the burial organic carbon in sediments deposited under anoxic conditions (Gill et al., 2011). The onset of the SPICE on the paleocontinent of Laurentia coincides with the extinction of trilobites (Saltzman et al., 2000), and the isotopic excursion has been correlated to intervals of biological turnover on other paleocontinents such as South China and Kazakhstan (Peng et al., 2004). The $\delta^{13} \mathrm{C}$ value of ocean may be influenced by changes in sea level and precipitating carbonates. Rising of sea level may result in negative excursion of $\delta^{13} \mathrm{C}$ peak values as transgressive flooding of anoxic bottom waters with a negative isotope signature for dissolved inorganic carbon on the shallow-water carbonate platform areas (Guo et al., 2010). On the other hand, 
sea level drop may result in increase in $\delta^{13} \mathrm{C}$ value of ocean. Sea level drop might have increased landderived $\delta^{13} \mathrm{C}$ values or lead to higher sedimentation rates that can enhance burial rate of organic matter (Kump and Arthur, 1999; Saltzman et al., 2004). Higher input of land-derived sediments during regression may result in increase of (1) nutrient supply to the ocean, (2) primary production, and (3) carbon burial. As a ressult such phenomena may lead to the high $\delta^{13} \mathrm{C}$ value of precipitating carbonates.

Depositional setting of the Machari Formation was reported to be carbonate ramp (Chung and Lee, 2002). During sea level fall the Machari Formation does not seem to be exposed to subaerial condition since no karst features associated with sea level fall has been found; therefore no unconformity is found during sea level lowstand. The trilobite biostratigraphy of the Machari is established by Lee (1995) and the FADs of G. reticulatus and Irvingella were reported. The SPICE event in the Cambrian carbonate platform in Korea has not been reported yet. This study provides the first high-resolution carbon isotope chemostratigraphy and sequence stratigraphy to reveal the SPICE event in the upper Cambrian sequence in the Yeongweol Group in Korea. Documentation of the SPICE event in the Machari Formation of the Yoengweol Group will be valuable to assess global correlation of the well-constrained trilobite biozones with other well-known Cambrian sections.

\section{Geologic Setting}

The Machari Formation which belongs to the Yeongweol Group (Table 1) (Choi, 1998) is Middle to Late Cambrian in age (Lee, 1995). It is distributed in the Yeongweol area where Cambro-Ordovician formations are distributed as N-S trending bands due to thrust (Fig. 1). The depositional setting of the Machari Formation was reported to be carbonate ramp (Chung and Lee, 2002) and it is partially dolomitized (Chung and Land, 1997). The Machari Formation overlies the Middle Cambrian Sambangsan Formation which is composed of siliciclastics such as laminated
Table 1. Stratigraphic classification of the lower Paleozoic Joseon Supergroup in the Yeongweol area

\begin{tabular}{lll}
\hline \hline \multicolumn{2}{c}{ Geologic age } & \multicolumn{1}{c}{ Choi (1998) } \\
\hline \multirow{3}{*}{ Ordovician } & $\begin{array}{l}\text { Caradoc } \\
\text { Llanvirn } \\
\text { Arenig }\end{array}$ & Yeongheung Fm. \\
\cline { 2 - 3 } & Tremadoc & Mungok Fm. \\
\hline \multirow{2}{*}{ Cambrian } & Late & Wagok Fm. \\
\cline { 2 - 3 } & Middle & Machari Fm. \\
\cline { 2 - 3 } & & Sambangsan Fm.
\end{tabular}

argillite, micaceous sandstone and sandy shale (Reinemund, 1957). The Machari Formation is in turn overlain by the Late Cambrian Wagok Formation, mainly consisted of massive dolomite (Woo and Moore, 1996). Overlying the Wagok Formation is the Ordovician Mungok Formation (Kim et al., 2003) which is interpreted to have been deposited on tidal flat (Paik et al., 1991) or subtidal ramp (Choi and Lee, 2000). The Mungok Formation is in turn overlain by the Yeongheung Formation which was thought to have been deposited on tidal flat (Choi and Woo, 1993; Kim et al., 1992; and Yoo and Lee, 1997).

\section{Methods}

Lithofacies was classified based on the sedimentary features including texture, composition and sedimentary structures which were identified by field and microscopic observations. Stratigraphic sections were measured at three localities including Eodungol, Gonggiri and Deogwoo where the Machari Formation is well exposed. Rock samples for petrographic and isotopic analyses were collected. For stable carbon and oxygen isotope analysis the cutting surface of mounted chip for making thin section was microdrilled to obtain small amounts $(2-3 \mathrm{mg})$ of powder. The location of spot for microdrilling was determined through observation under the polarizing microscope. Microdrilling was conducted on the least altered part such as micrite as possible. Stable isotope analysis was performed at GNS Science in New Zealand using the Europa Carbonate Automated 


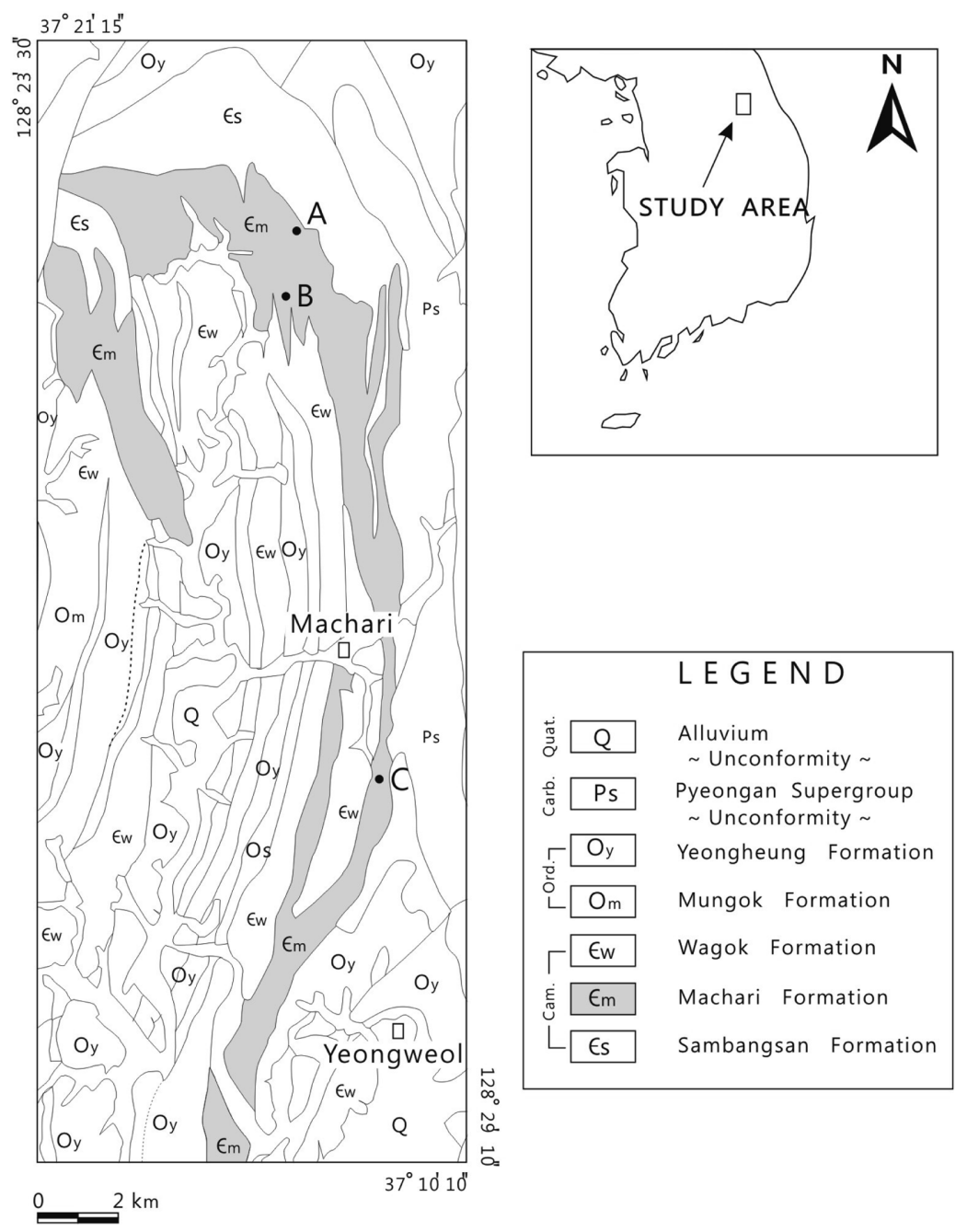

Fig. 1. Geologic map showing distribution of the Machari Formation in the Yeongweol area (GICTR, 1962; Choi, 1998) and three localities (A Eodungol, B Gonggiri, and C Deogwoo) investigated in this study.

Preparation System at a reaction temperature of $80^{\circ} \mathrm{C}$ and run via Dual Inlet on the GEO 20-20 mass spectrometer. All results are reported with respect to VPDB, normalized to the internal standards of GNS marble with reported values of $2.0 \%$ for $\delta^{13} \mathrm{C}$ and $-6.4 \%$ for $\delta^{18} \mathrm{O}$. The analytical precision for these measurements are $0.3 \%$ for $\delta^{13} \mathrm{C}$ and $0.3 \%$ for $\delta^{18} \mathrm{O}$.

\section{Lithofacies and Facies Associations}

The Machari Formation has been reported to be composed of 7 lithofacies; they are bedded lime mudstone facies, laminated lime mudstone facies, bioclastic/peloidal packstone to grainstone facies, peloidal/bioclastic wackestone facies, conglomerate facies, mottled lime mudstone facies, and shale facies (Chung and Lee, 2002). Further investigation in this study, however, shows that the Machari Formation consists of 5 lithofacies and 2 facies associations. Lithofacies of the Machari Formation in this study are bedded limestone facies, laminated limestone facies, bioclastic/peloidal packstone to grainstone facies, lime conglomerate facies, and shale facies. Two facies associations are facies association I (mid ramp) and facies association II (outer ramp). In this study peloidal/bioclastic wackestone facies and mottled lime 
mudstone facies reported by Chung and Lee (2002) are classified into bedded limestone facies. Although these two facies has been regarded as distinctive characteristics as separate lithofacies by Chung and Lee (2002), these facies mostly occur in bedded facies and therefore it is classified as bedded facies in this study. In addition facies association III, which was reported to be the basin by Chung and Lee (2002) occurs very little, only a few meter interval. Consequently, in this study this facies association is modified to be outer ramp setting. Description and interpretation of lithofacies and facies associations are as follows.

\section{Lithofacies}

\section{Bedded limestone}

Description: This facies consists of three types of alternation of limestone and marl or shale, i.e., parted limestone, ribbon limestone, and nodular limestone. The parted limestone consists of 3 to $10 \mathrm{~cm}$ thick limestone bed which is separated by a few mm thick shaley or marly laminae (Fig. 2A). Limestone beds forming parted limestone consist of two types; mmthick laminae and massive bed. Limestone beds with mm-thick laminae are more common than massive limestone bed. The ribbon limestone shows alternation of 2 to $5 \mathrm{~cm}$ thick limestone bed with equally thick or slightly thin marl or shale bed (Figs. 2B and C). The limestone beds of ribbon limestone also show mmthick lamination. The parted and ribbon limestone beds show relatively good horizontal continuity. The nodular limestone consists of nodular-shaped limestone bed alternated with dark shale or dolomitic shale; the limestone beds are a few tens of centimeters long and 2 to $7 \mathrm{~cm}$ thick, and shale or dolomitic shale layers are slightly thinner than limestone beds (Fig. 2D). Limestone bed in nodular limestone contains laminae but some are massive bed. Sometimes low angle cross-laminations are found. The massive beds show sharp lower contact and gradational change to bedded limestone in upward direction. The dolomitic shale in nodular limestone is protruded on the weathered surface. Some parted and ribbon limestone are bioturbated. The bioturbated mottles are several millimeters to several centimeters in size and their shapes are irregular to circular (Fig. 2E); they show dark gray color on fresh surface and brown color on weathered surface. It shows gradational boundaries with underlying facies and degree of bioturbation decreases downward and irregularly disturbed layers gradually change into bedded facies. In microscopic observation the bedded limestone consists of lime mudstone with some wackestone, packstone and grainstone (Fig. 2F). Most of lime mud has been recrystallized to microspar and spar. Allochems are bioclasts and peloids. Disarticulated trilobite and brachiopods are common bioclasts. The bedded limestone occurs as discrete beds alternating with other lithofacies and some beds are massively dolomitized. The uppermost part of the Machari Formation is mostly composed of bedded limestone which is often massively dolomitized. Pressure solution features including stylolite and wispy seams are observed. Under the microscope mottles consist of subhedral to anhedral interlocking dolomite and lime mudstone composed of micrite and microspar. The boundary between limestone and marl in the ribbon limestone is gradational (Fig. 2G).

Interpretation: Good horizontal continuity and welldeveloped parallel layer suggest relatively deep water deposition. Parallel lamination in limestone bed suggests influx of carbonate sediments as event. The depositional setting of the Machari Formation might have been carbonate ramp as suggested by lack of slumps and slide scars. Outflow of carbonate sediments from inner ramp or shallow water platform to middle to outer ramp environment due to storm activity is suggested for the deposition of ribbon limestone (Elrick et al., 1991). The carbonates are thought to have been deposited as turbidity current deposits where siliciclastic mud is settling almost at constant rate. The depositional setting of the bedded limestone including parted, ribbon and nodular limestone is interpreted to be mid ramp. Most of the 

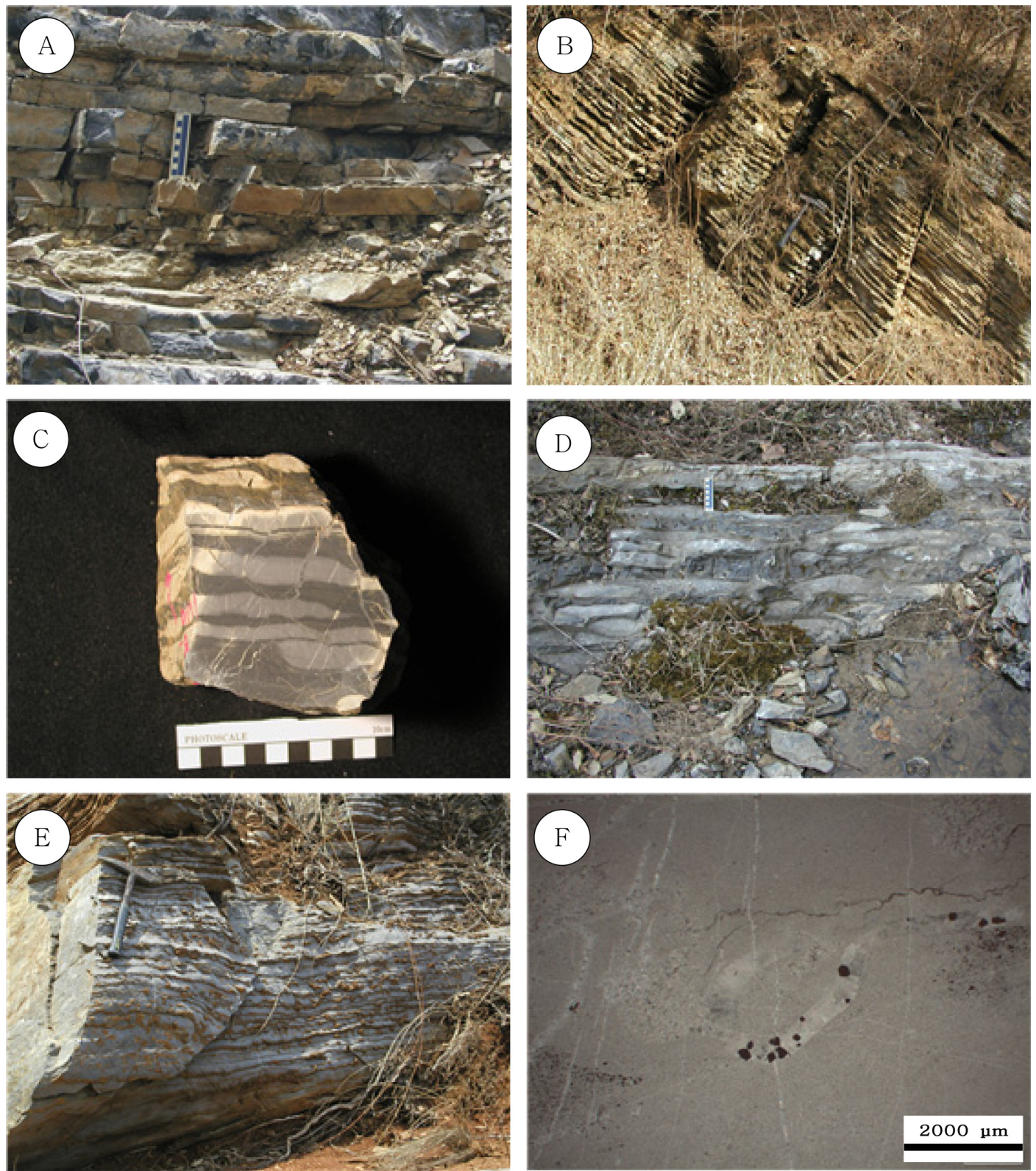

Fig. 2. Features of lithofacies. A. Field photograph of parted limestone characterized by relatively thick lime mudstone bed alternating with relatively thin argillaceous laminae. B. Field photograph of ribbon rock characterized by equal thickness of limestone and argillaceous limestone layers. C. Rock slab photograph of ribbon rock. Scale bar is in centimeter. D. Field photograph of nodular lime mudstone showing nodular to lenticular bed of limestone with relatively thin argillaceous layer. E. Field photograph of the mottled limestone which is classified as bedded limestone in this study. F. Photomicrograph of parted limestone consisted of bioclastic wackestone. In cross-polarized light.

bedded limestone might have been deposited below fair-weather wave base. Presence of low angle cross laminae may suggest that the depositional setting of the bedded limestone was influenced by storm. Each mm-thick laminae of limestone beds may represent single event of turbidity currents. Alternation of a few cm-thick limestone and shale beds may represent millennial-scale paleoclimate cycles (Elrick and 

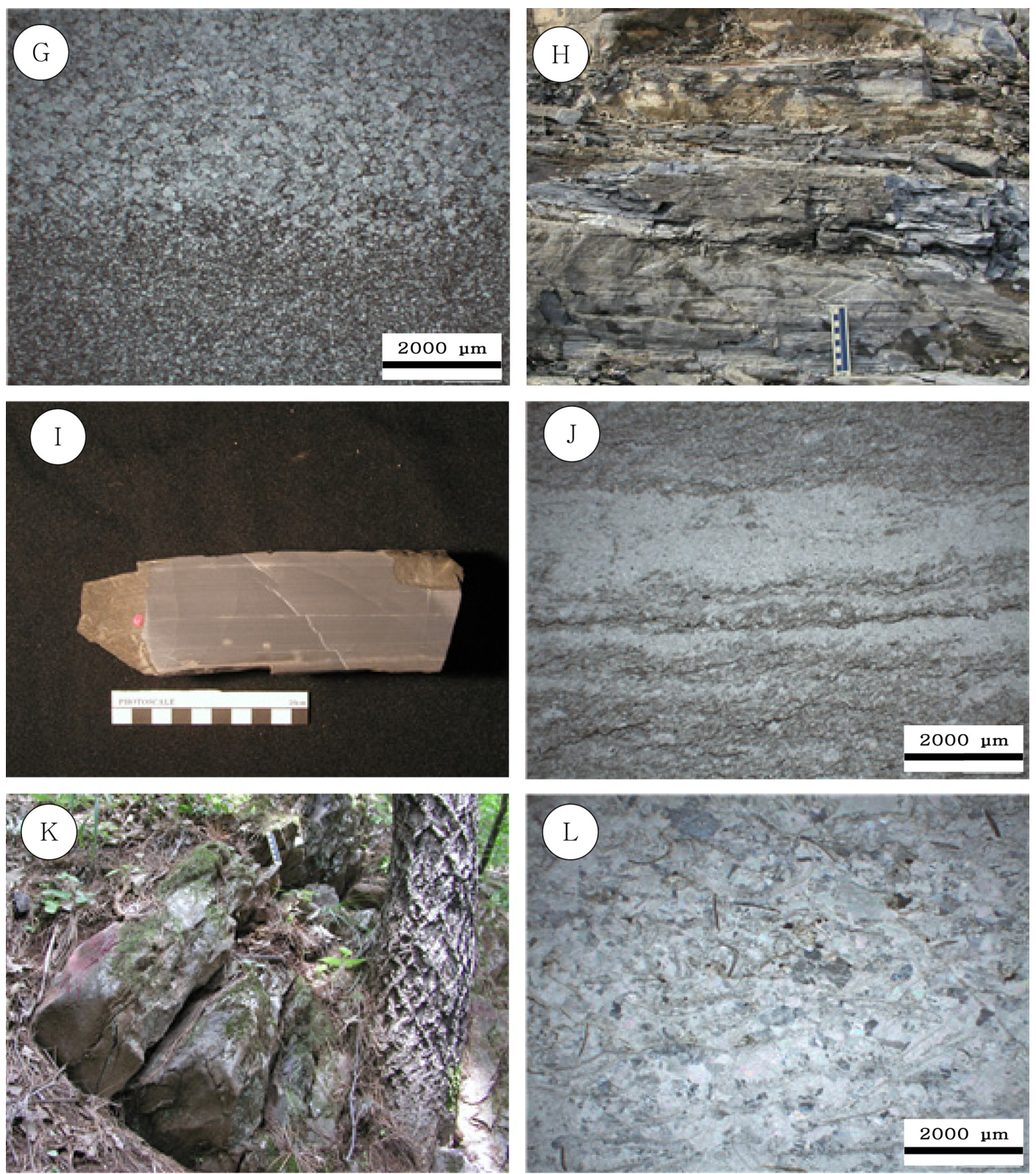

Fig. 2. Continued. G. Photomicrograph of ribbon limestone showing limestone layer alternating with marl layer; limestone layer is composed of the sparry calcite, and marly layer is composed of mixture of micrite to microsparry calcite with clay minerals. In plane-polarized light. H. Field photograph of laminated limestone of dark gray characterized by limestone laminae alternating with argillaceous limestone laminae. I. Rock slab of laminated limestone showing well-developed parallel laminae. J. Photomicrograph of laminated lime mudstone facies showing limestone laminae (bright layer) alternating with argillaceous lime mudstone laminae (dark layer). In plane-polarized light. K. Field photograph of bioclastic/peloidal grainstone to packstone. L. Photomicrograph of bioclastic/peloidal packstone to grainstone mostly composed of bioclasts. In cross-polarized light.

Hinnov, 2007). During dry period more carbonate sediments from shallow water carbonate platform were introduced to deeper outer area, i.e. mid ramp whereas during humid period more clays derived from land were introduced to mid ramp. Nodular limestone may have been formed by diagenetic origin (Kim and Lee, 

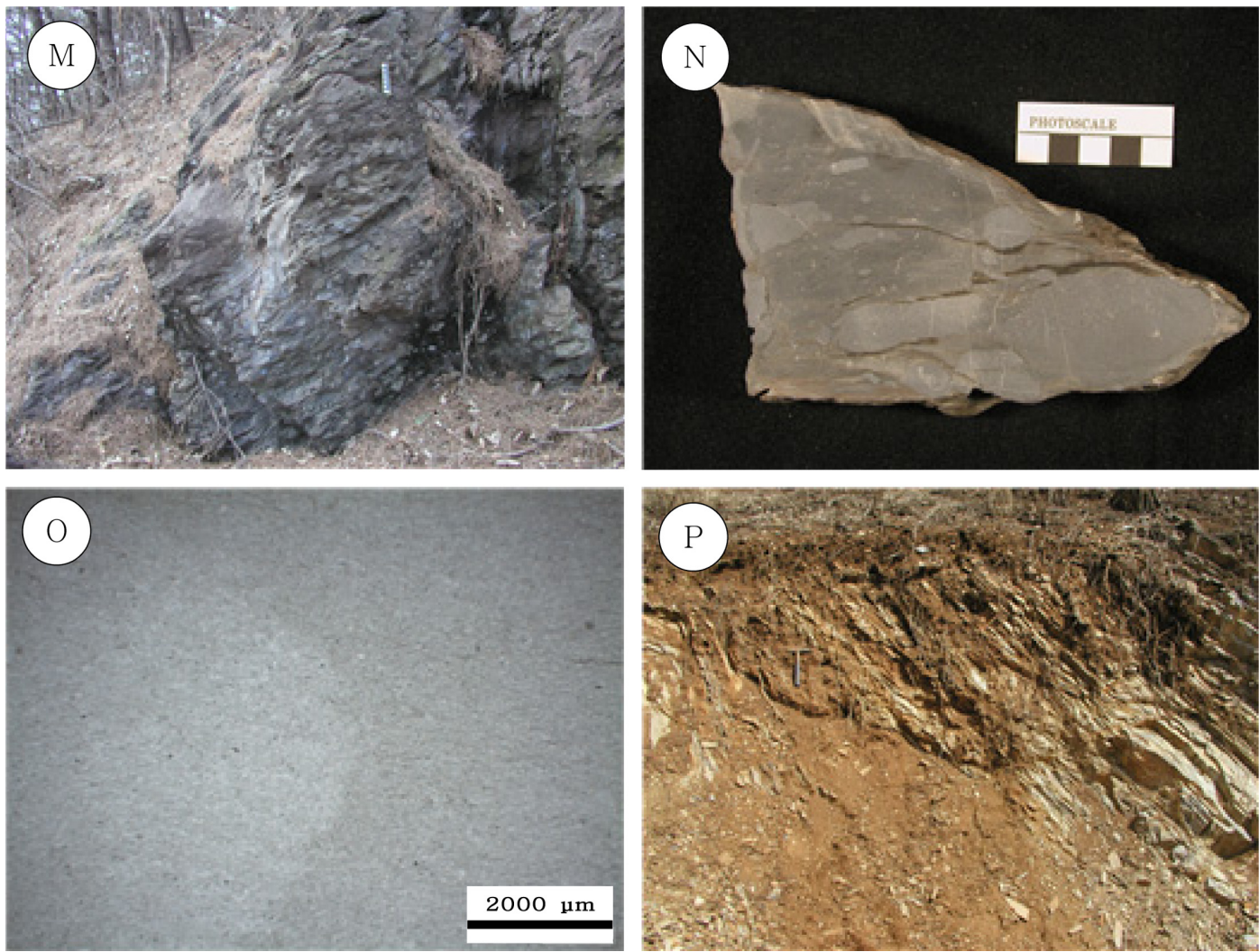

Fig. 2. Continued. M. Field photograph of lime conglomerate; the content of limestone gravels consisting of pebble to cobble size is 30 to $40 \%$. M. Rock slab of lime conglomerate. O. Photomicrograph of lime conglomerate showing limestone gravel of bright color in the left. Lime conglomerate is composed of micrite. P. Field photograph of shale.

1996). During diagenesis differential cementation in limestone and shale layer which were formed originally as parted or ribbon limestone seems to have been resulted in differential compaction during burial and formation of nodular limestone.

\section{Laminated limestone}

Description: The laminated limestone consists of a few mm-thick dark gray to gray limestone alternating with equally or slightly thin dark gray or black shale (Figs. 2H and I). This facies shows good horizontal continuity. The thickness of this facies is a few centimeters to tens of meters. In microscopic observation the limestone laminae are alternating with argillaceous laminae (Fig. 2J). The limestone laminae consist of microspar and contain some dolomitic rhombs. Trilobite bioclasts indicative of deep or pelagic water such as Glyptagnostus, Aspidagnostus, Innitagnostus, Pseudoagnostus, Ivshinagnostus, Agnostotes, Olenus, Irvingella, Erixanium, and Proceatopyge were found in this lithofacies (Lee, 1995).

Interpretation: Alternation of thin laminae consisted of dark gray to black lime mudstone and shale suggests deep water deposition, presumably in anoxic condition. Fine-grained carbonates with good horizontal continuity suggest pelagic deposits. Finely laminated lime mudstone alternating with shale is interpreted to have been deposited as distal turbidite on the outer ramp where clays were settling slowly.

\section{Bioclastic/peloidal packstone to grainstone}

Description: This facies is thickly bedded, tens of centimeters to several meters thick, and shows light 
gray to gray color (Fig. 2K). This facies occurs mainly in the lower and upper part of Eodungol section. This facies does not show good horizontal continuity with relatively sharp lower contact. Sometimes the lower boundaries are irregular with scour surface, and load and flame structures. In microscopic observation allochems show medium to coarse sand sizes of bioclasts (Fig. 2L) with minor amount of peloids and intraclasts. Bioclasts consist of fragments of trilobites and brachiopods, and peloids consisted of brownish micrite of circular to elliptic shape. Some algae such as Girvanella are also found. Some bioclasts show geopetal structure. Some intraclasts consist of subangular to rounded algal aggregates of 0.5 to $30 \mathrm{~mm}$ in size. Other grains of limestone are some oncoids and cortoids. Oncoids consist of circular- to elliptic-shaped algal or micritic laminae. Cortoids consist of peloids or bioclasts cores surrounded by micritic envelopes. Trilobites in this facies include Tonkinella, Olenoides, Kootenia, and Peronopsis. Overlying this facies is laminated lime mudstone and shale facies.

Interpretation: Occurrence of bioclasts indicating shallow water depth in association with deep water facies such as laminated lime mudstone and shale facies suggests transportation of shallow water bioclasts to relatively deep water environment. Occurrence of Girvanella intraclasts suggests origin of sediment from algal bioherm in photic zone. Shallow water bioclasts and peloids are thought to have been transported by turbidity currents to deep water presumably below the fair weather wave base; however, mostly above the storm wave base (Lubeseder et al., 2009). Massive grains with scour and grading also suggest turbidite deposits.

\section{Lime conglomerate}

Description: Lime conglomerate facies consists mostly of pebble-sized clasts of lime mudstone, dolomitized lime mudstone or peloidal packstone (Figs. 2M and $\mathrm{N}$ ). Lime conglomerate is mostly matrix-supported. The matrix is lime mud or shaley dolomite. Grains are randomly oriented or subparallel to the bedding surface. They are planar to elongate shape, angular to subrounded, and poorly sorted. In some area they show reverse grading followed by normal grading. This facies is 30 to $50 \mathrm{~cm}$ thick but the thickness varies laterally. In some parts the thickness reaches up to $200 \mathrm{~cm}$. The lower and upper contacts are relatively sharp. Along the lower contact scour mark and deformed underlying bed are observed. In microscopic observation lime mudstone clasts consist of micrite and microspar (Fig. 20). Dolomitized clasts consist of interlocking dolomite. Peloidal packstone clasts consist of silt-sized peloids. Matrix between clasts consists of argillaceous lime mud with peloids and bioclasts.

Interpretation: Sharp boundaries and random to subparallel orientation of grains suggest event deposit such as storm. Partially lithified lime mudstone and peloidal packstone are thought to have been broken by storm activities and transported nearby. High-energy storm waves could break the semilithified carbonate layers into clasts, which were then deposited nearby forming lime conglomerates (Glumac and Walker, 2000; Seguret et al., 2001).

\section{Shale}

Description: Shale facies consists of dark gray to black shale with laminations and fissilities, but some of them show brownish color on weathered surface (Fig. 2P). Laminations show good horizontal continuity. The thickness of shale facies is several centimeters to 1.5 meters. This facies occurs in association with laminated lime mudstone facies.

Interpretation: Lack of shallow water features such as scour marks, mud cracks, and ripple cross laminations suggests relatively deep water deposition below storm wave base. Laminations with good horizontal continuity suggest pelagic settling. Dark gray to black color suggests anoxic environment presumably in the oxygen minimum layer. 


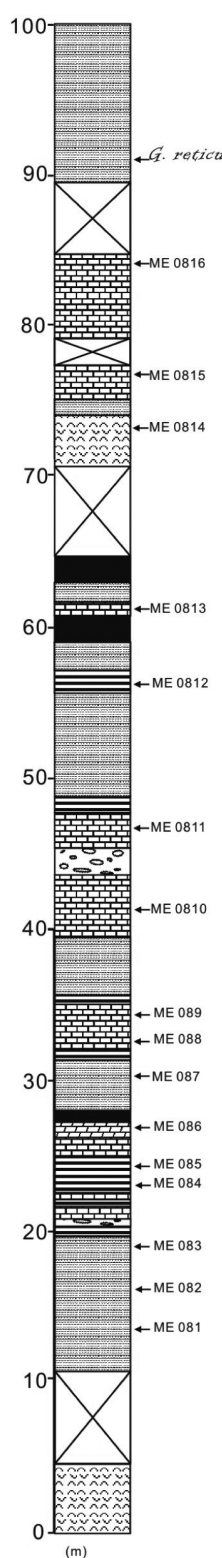

A

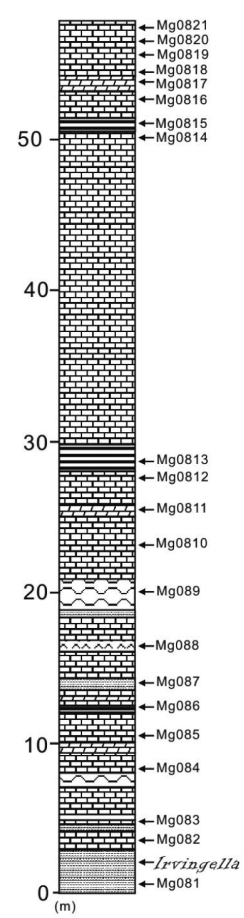

B
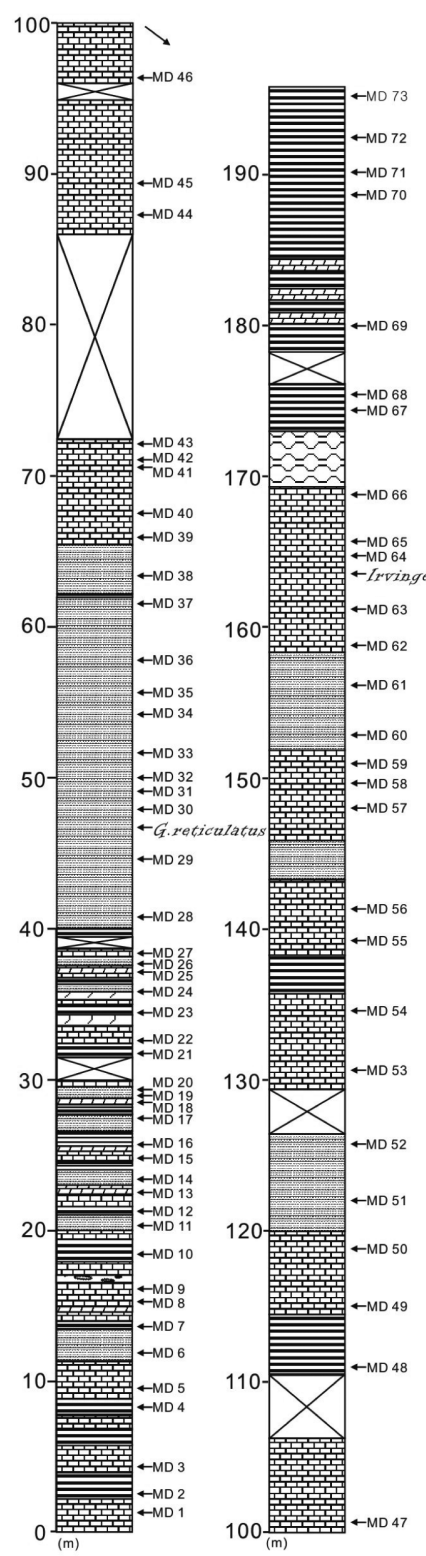

\section{LEGEND}

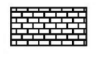

Parted limestone

Dolomite

Eibbon Limestone

$=0$ Nodular limestone

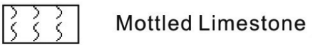

Laminated limestone

Bioclastic/Peloidal Packstone to Grainstone

:-: Lime Conglomerate

Shale

Fig. 3. Stratigraphic sections measured at three localities. A Eodungol, B Gonggiri, and C Deogwoo. Samples for stable carbon isotope analysis were indicated by arrows with sample numbers.

\section{Facies Associations}

Stratigraphic sections of the Machari at three localities are shown in Fig. 3. The facies in the Machari Formation can be grouped into depositional settings; mid and outer ramps (Fig. 4) which are equivalent to facies association I and II, respectively.
The facies deposited on the mid ramp setting (facies association I) consists of bedded limestone facies, conglomerate facies, and bioclastic/peloidal packstone to grainstone facies (Fig. 4). Mid ramp depositional setting of facies is characterized by frequent occurrence of allochems in bioclastic/peloidal packstone to grainstone, relatively thick limestone layer such as 
Table 2. Values of stable carbon isotope from samples in three sections of the Machari Formation

\begin{tabular}{|c|c|c|c|c|c|}
\hline Sample location & Sample number & $\delta^{13} \mathrm{C}(\%)$ & Sample location & Sample number & $\delta^{13} \mathrm{C}(\% \mathrm{o})$ \\
\hline Eodungol & ME081 & -1.8 & Deogwoo & MD40 & 4.1 \\
\hline Eodungol & ME082 & -1.4 & Deogwoo & MD41 & 3.8 \\
\hline Eodungol & ME083 & -0.8 & Deogwoo & MD42 & 3.8 \\
\hline Eodungol & ME084 & 0.5 & Deogwoo & MD43 & 3.5 \\
\hline Eodungol & ME085 & 0.3 & Deogwoo & MD44 & 4.2 \\
\hline Eodungol & ME086 & -1.4 & Deogwoo & MD45 & 4.2 \\
\hline Eodungol & ME087 & -1.0 & Deogwoo & MD46 & 3.4 \\
\hline Eodungol & ME088 & 0.7 & Deogwoo & MD47 & 3.3 \\
\hline Eodungol & ME089 & 0.5 & Deogwoo & MD48 & 3.3 \\
\hline Eodungol & ME0810 & -0.5 & Deogwoo & MD50 & 3.0 \\
\hline Eodungol & ME0811 & -0.8 & Deogwoo & MD51 & 3.4 \\
\hline Eodungol & ME0812 & -0.5 & Deogwoo & MD52 & 3.6 \\
\hline Eodungol & ME0813 & 0.2 & Deogwoo & MD53 & 3.5 \\
\hline Eodungol & ME0814 & 2.5 & Deogwoo & MD54 & 3.8 \\
\hline Eodungol & ME0815 & 2.1 & Deogwoo & MD55 & 4.3 \\
\hline Eodungol & ME0816 & 2.4 & Deogwoo & MD56 & 4.4 \\
\hline Deogwoo & MD1 & 1.1 & Deogwoo & MD57 & 4.2 \\
\hline Deogwoo & MD2 & 0.9 & Deogwoo & MD58 & 3.9 \\
\hline Deogwoo & MD3 & 1.1 & Deogwoo & MD59 & 3.7 \\
\hline Deogwoo & MD4 & 1.3 & Deogwoo & MD60 & 4.0 \\
\hline Deogwoo & MD5 & 1.2 & Deogwoo & MD61 & 4.0 \\
\hline Deogwoo & MD6 & 0 & Deogwoo & MD62 & 4.1 \\
\hline Deogwoo & MD7 & 1.1 & Deogwoo & MD63 & 2.8 \\
\hline Deogwoo & MD8 & 1.3 & Deogwoo & MD64 & 2.8 \\
\hline Deogwoo & MD9 & 0.7 & Deogwoo & MD65 & 2.4 \\
\hline Deogwoo & MD10 & 0.8 & Deogwoo & MD66 & 1.7 \\
\hline Deogwoo & MD11 & 0.6 & Deogwoo & MD67 & 1.9 \\
\hline Deogwoo & MD12 & 0.6 & Deogwoo & MD69 & 1.5 \\
\hline Deogwoo & MD13 & 1.0 & Deogwoo & MD70 & 1.8 \\
\hline Deogwoo & MD14 & 0.9 & Deogwoo & MD71 & 2.0 \\
\hline Deogwoo & MD15 & 1.2 & Deogwoo & MD72 & 1.6 \\
\hline Deogwoo & MD16 & 0.9 & Deogwoo & MD73 & 1.6 \\
\hline Deogwoo & MD17 & 0.8 & Deogwoo & MG081 & 0.7 \\
\hline Deogwoo & MD18 & 0.9 & Gonggiri & MG082 & 0.5 \\
\hline Deogwoo & MD19 & 0.6 & Gonggiri & MG083 & 0.6 \\
\hline Deogwoo & MD20 & 0.9 & Gonggiri & MG084 & 0.5 \\
\hline Deogwoo & MD21 & 0.2 & Gonggiri & MG085 & 0.9 \\
\hline Deogwoo & MD22 & 0.5 & Gonggiri & MG086 & 1.2 \\
\hline Deogwoo & MD23 & 0.6 & Gonggiri & MG087 & 1.4 \\
\hline Deogwoo & MD24 & 0.1 & Gonggiri & MG088 & 1.1 \\
\hline Deogwoo & MD25 & 0.7 & Gonggiri & MG089 & 0.8 \\
\hline Deogwoo & MD26 & 1.1 & Gonggiri & MG0810 & 0.5 \\
\hline Deogwoo & MD27 & 1.2 & Gonggiri & MG0811 & 0.7 \\
\hline Deogwoo & MD28 & 1.1 & Gonggiri & MG0812 & 0.2 \\
\hline Deogwoo & MD29 & 1.2 & Gonggiri & MG0813 & 1.4 \\
\hline Deogwoo & MD30 & 0.8 & Gonggiri & MG0814 & 0.8 \\
\hline Deogwoo & MD31 & 0.6 & Gonggiri & MG0815 & 0.7 \\
\hline Deogwoo & MD32 & 1.3 & Gonggiri & MG0816 & 0.9 \\
\hline Deogwoo & MD33 & 2.2 & Gonggiri & MG0817 & 1.0 \\
\hline Deogwoo & MD34 & 2.3 & Gonggiri & MG0818 & 0.9 \\
\hline Deogwoo & MD35 & 2.0 & Gonggiri & MG0819 & 0.7 \\
\hline Deogwoo & MD36 & 3.0 & Gonggiri & MG0820 & 0.4 \\
\hline Deogwoo & MD37 & 3.4 & Gonggiri & MG0821 & 0.7 \\
\hline Deogwoo & MD38 & 3.6 & Gonggiri & MG0822 & -0.2 \\
\hline Deogwoo & MD39 & 2.6 & Gonggiri & & \\
\hline
\end{tabular}




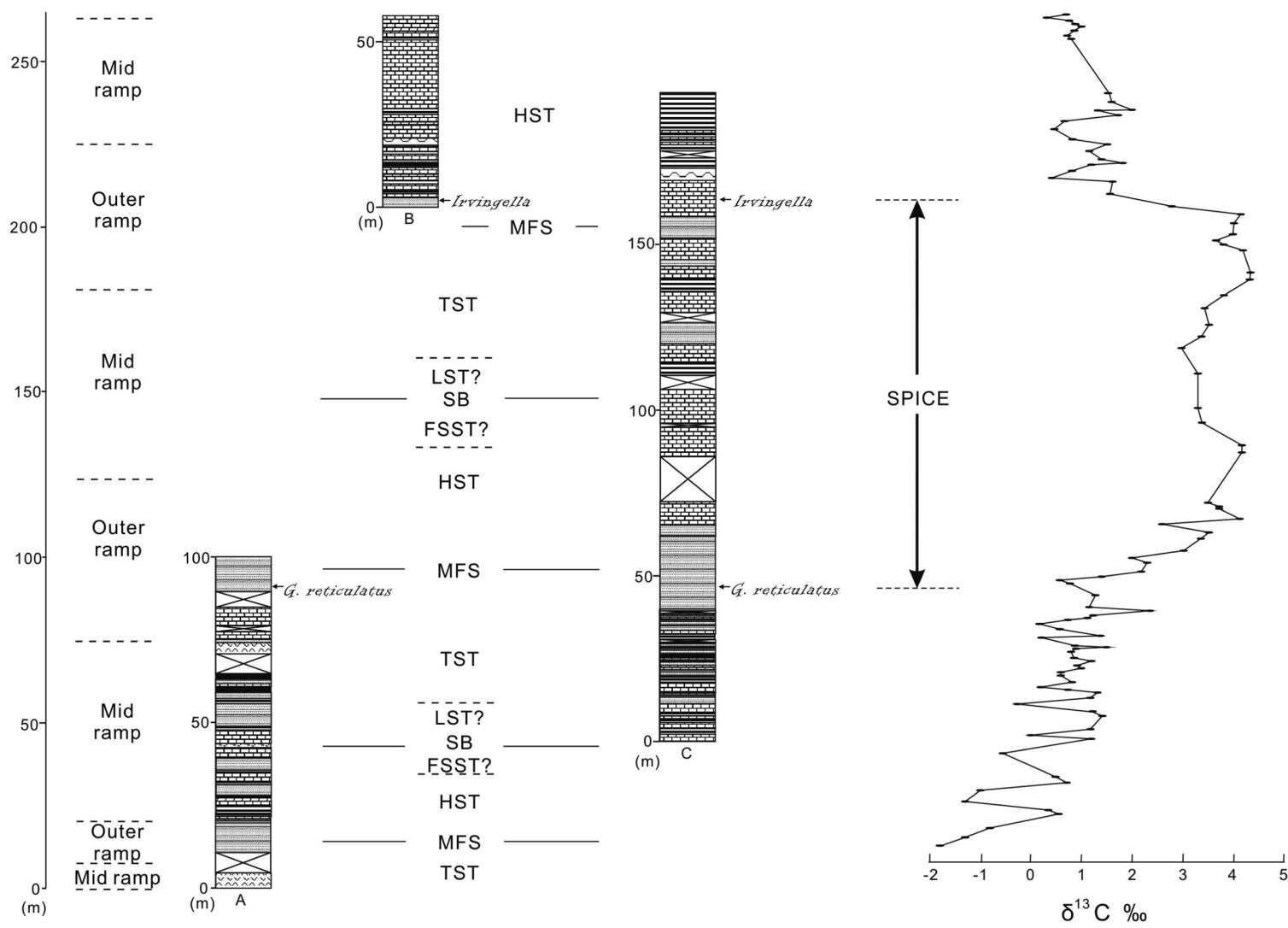

Fig. 4. Correlation of three stratigraphic sections (A Eodungol, B Gonggiri, and C Deogwoo) based on trilobite biostratigraphy, depositional setting, sequence stratigraphy, and $\delta^{13} \mathrm{C}$ stratigraphy of the Machari Formation. The SPICE interval (ca. 120m thick) corresponds to the stratigraphic interval from the first appearance datum (FAD) of trilobite G. reticulatus and to the FAD of trilobite Irvingella. The sequence stratigraphic interval of the SPICE corresponds to HST to TST.

parted and ribbon limestone. Allochems in packstone and grainstone are suggested to have been derived from shallow water depths by agitation and then transported offshore direction by turbidity currents. Relatively thick limestone layers suggest proximal source of carbonate grains. Alternation of limestone layer with marl layer is thought to have been formed by influx of carbonates by turbidity currents on the mid to outer ramp where argillaceous lime mud was settling from water column. Occurrence of limestone conglomerates suggests deposition by storm activities above the storm wave base. The semilithified carbonate layers might be broken limestone gravel by high-energy storm activities, which were then deposited to form lime conglomerates. Lack of indicator of wave action such as scour marks and ripples in the conglomerate facies suggests depositional setting below the fair weather wave base.

The facies on the outer ramp setting (facies association II) consists of bedded facies, bioclastic/ peloidal packstone to grainstone facies, laminated lime facies, and shale facies (Fig. 4). Compare to the mid ramp setting, the outer ramp deposits are characterized by more occurrence of laminated facies. Deposition of facies association of II below the storm wave base is suggested by lack of features associated with shallow water carbonates such as scour marks, mud cracks, and ripple cross laminations. Lack of slump and slide features which are commonly associated with carbonate ramp suggests slope angle of depositional environment for the Machari Formation is low. Laminations and thin beds in the outer ramp are suggested to have 
been formed by intermittent influx of shallow water lime mud as turbidity currents on the carbonate outer ramp where argillaceous mud was settling at relatively constant rate as pelagic mud. The outer ramp setting during the deposition of facies association II might have been anoxic condition as suggested by dark gray and black calcareous shale. The depths to deposit the facies association II might be below storm wave base. In the ocean low oxygen concentration occurs at 120 to $180 \mathrm{~m}$ depth (Duxbury and Duxbury, 1996). Consequently, facies association II is interpreted to have been deposited on the outer carbonate ramp in the oxygen minimum layer below the storm wave base.

\section{Stable Carbon Isotopes}

The stable carbon isotope values of the Machari Formation are shown in Table 2. The SPICE in the Machari Formation occurs between the first appearance datum (FAD) of trilobite G. reticulatus and the FAD of trilobite of Irvingella (Fig. 4). The $\delta^{13} \mathrm{C}$ values of SPICE in the Machari Formation vary from $0.6 \%$ which coincides approximately with the FAD of trilobite G. reticulatus and increase upsection as high as $4.4 \%$, and then decrease to $1.7 \%$ which coincides with the stratigraphic position of the FAD of trilobite Irvingella (Fig. 4). The stratigraphic interval of positive excursion of $\delta^{13} \mathrm{C}$ values is about $120 \mathrm{~m}$ (Fig. 4).

\section{Discussion}

\section{Sequence Stratigraphy}

The Machari Formation is interpreted to have deposited as transgressive systems tract (TST) at the beginning and was followed by highstand systems tract (HST). Three cycles of TST to HST were observed in the Machari Formation (Fig. 4).

\section{Transgressive Systems Tract}

TST in the Machari Formation occurs as deepening upward sequence. Deepening upward sequence consists of bedded limestone or bioclastic packstone to grainstone overlain by laminated limestone. TST occurs three times in the Machari Formation. The lowermost part of the Machari Formation begins with the TST which is composed of bioclastic packstone to grainstone which overlies the siliciclastic Sambangsan Formation and the contact between them is observed at Eodungol section. With rise of sea level carbonates were begun to deposit on the siliciclastic substrate, the Sambangsn Formation. The depositional setting of the early transgressive event might be mid ramp. The Machari Formation shows three TSTs (Fig. 4). With rise of sea level the mid ramp deposits were overlain by outer ramp deposits which are mainly composed of laminated limestone and some ribbon and parted limestone (Figs. $3 \& 4$ ). The first maximum flooding surface (MFS) was developed during the time when the Machari Formation was deposited on the outer ramp. The outer ramp deposits was in turn overlain by mid ramp deposits and HST was developed. The HST might have been followed by falling stage systems tract although the boundary between the HST and the falling stage systems tract (FSST) is speculative. After the development of HST/FSST, the sequence boundary (SB) was developed. During the development of the first $\mathrm{SB}$, the parted limestone is thought to have been deposited (Fig. 4). The TST ends with maximum flooding surface. The second MFS might be located at the middle of laminated limestone interval in the Deogwoo section and the third one is found in the upper part of the Deogwoo section and for the Gonggiri section MFS is not exposed (Fig. 4). During the maximum flooding laminated limestone was deposited.

\section{Highstand Systems Tracts/Falling Stage and Lowstand Systems Tracts}

The HST in the Machari Formation overlies the TST and is characterized by the shallowing upward sequence showing a sequence of laminated limestone overlain by parted and ribbon limestone. Shallowingupward sequence might have been formed by input of shallow water carbonate by density currents largely by 
turbidity current during highstand of sea level. Sediments above the storm wave base might have been suspended and transported basinward as turbidity currents. The lower boundary of HST is MFS and its upper boundary is regressive surface of marine erosion (RSME), or basal surface of forced regression (BSFR), or subaerial unconformity (Catuneau, 2006). The RSME is thought to be formed by wave erosion due to the lowering of the fair weather wave base during base level fall (Catuneau, 2006), i.e., it must have been formed above the fair weather wave base. However, in the Machari Formation RSME was not found as the sequence is thought to have been deposited below the fair weather wave base.

The HST is followed by the FSST. The FSST in the carbonate ramp is thought to be represented by shallowing of substrate and the deposits are characterized by shallowing upward sequence which is similar to siliciclastic shelf system (Catuneau, 2006). The boundary between the HST and the FSST is the basal surface of forced regression (Catuneau, 2006). In the Machari Formation no subaerial exposure of carbonate platform was identified during sea level fall since it was deposited on the carbonate ramp. The FSST in the Machari Formation may occur as ribbon and parted limestone. However, the boundary between the HST and FSST is speculative in the Machari Formation because the depositional setting of the Machari Formation was carbonate ramp and no distinctive facies change was observed during sea level fall. The FSST is followed by the LST which is characterized by sedimentation rate outpacing the rate of base-level change and it is termed as normal regression (Catuneau, 2006). The base of the LST is defined by the maximum regression and shallowest facies observed within the sequence (Lubeseder et al., 2009). The LST in the Machari Formation may be represented by occurrence of shallow water deposits, i.e. the mid ramp deposits which are composed of parted and ribbon limestone. However, the exact boundaries between the HST and FSST, and LST and TST are speculative in the Machari Formation.

\section{Sequence Boundaries}

Two sequence boundaries are proposed in the Machari Formation in context of sequence stratigraphy. In the Machari Formation no subaerial exposure surfaces has been identified in the stratigraphic sections as the depositional setting was thought to be mid to outer carbonate ramp. With sea level fall the depositional setting became mid ramp and the deposition in the Machari Formation must have occurred at maximum regression during which correlative conformity was formed instead of subaerial unconformity. During the maximum regression the bedded limestone such as the parted and ribbon limestone is interpreted to have been deposited.

\section{SPICE}

For the cause of the SPICE anoxic ocean was suggested (Saltzman et al., 2004; Gill et al., 2011). Occurrence of darkly laminated marl and limestone below the SPICE interval in the Machari Formation suggests the burial of organic matter in deeper part of ocean, presumably in oxygen minimum zone which removed isotopically light ${ }^{12} \mathrm{C}$ isotope and left heavy ${ }^{13} \mathrm{C}$ isotope in the ocean. The paleoenvironmental condition prior to form the SPICE must be an anoxic condition which was associated with mass extinction of trilobite. The onset of the SPICE approximately coincides with a dramatic extinction of trilobites in Laurentia (Saltzman et al., 2000; Peng et al., 2004). Similar horizon of mass extinction was reported approximately at the FAD of $G$ reticulatus in Australia (Saltzman et al., 2000). This extinction of trilobites may be caused by cooling events that may have been resulted from sea level rise and subsequent rise of thermocline, and thereby the environment was changed to oxygen-poor and cooler water.

Sea level fluctuation may affect the variation of $\delta^{13} \mathrm{C}$ value of ocean. Rising of thermocline in accordance with sea level fluctuation can cause $\delta^{13} \mathrm{C}$ value of ocean. The rise of sea level might have led a rise of the thermocline causing flooding of cool 
anoxic water on the shelves (Ahlberg et al., 2009), which may result in negative excursion of $\delta^{13} \mathrm{C}$ peak values as transgressive flooding of anoxic bottom waters with a negative isotope signature for dissolved inorganic carbon on the shallow-water carbonate platform areas (Guo et al., 2010). Rising of anoxic bottom waters may lead to oxidation of organic matter due to recycling of organic carbon in shallow-water carbonate platform and result in depletion of ${ }^{13} \mathrm{C}$ in precipitating carbonates. However, in the Machari Formation the occurrence of the SPICE interval in the TST suggests that flooding of anoxic water might have not occurred to deplete the $\delta^{13} \mathrm{C}$ value of the ocean.

On the other hand, glacio-eustatic drop might increase riverine $\delta^{13} \mathrm{C}$ values (Kump and Arthur, 1999) or lead to higher sedimentation rates that enhance burial of organic matter (Saltzman et al., 2004). Higher weathering rates of silicate- or phosphate-rich sedimentary rocks during regression may result in enhancement of nutrient delivery to shelf regions and increase primary production and carbon burial (Saltzman et al., 2004) and increase in ${ }^{13} \mathrm{C}$ in ocean and the precipitating carbonates. In Laurentia the SPICE interval is coincident with lowstand of sea level indicated by an unconformity between Sauk II and Sauk III sequences (Saltzman et al., 2004). The association of maximum $\delta^{13} \mathrm{C}$ values with lowstand of sea level suggests that enhanced rates of weathering and erosion of exposed land led to an increase in rate of burial of organic carbon in siliciclastic deposits in ocean (Saltzman et al., 2004; Glumac and Mutti, 2007). In the Machari Formation lowstand of sea level during the SPICE event is indicated by the deposition of shallow water lithofacies. Most of the lithofacies in the SPICE interval of the Machari Formation is composed of bedded limestone (parted and ribbon limestone).

The occurrence of SPICE in the world shows two discrepancies, stratigraphic age and peak $\delta^{13} \mathrm{C}$ values. The onset and the stratigraphic age of the peak values of the SPICE seems to be diachronous and vary between regions (Ahlberg et al., 2009). In South
China the onset of the excursion seems to begin below the FAD of G. reticulatus, Zone (Peng et al., 2004). In Kazakhstan, the onset of the excursion seems to begin in the G. stolidotus Zone (corresponding to the upper part of the A. pisiformis Zone) (Saltzman et al., 2000). In Iowa, the peak value is reached in the Dunderbergia Zone (Saltzman et al., 2004). The peak values of the SPICE in the Machari Formation is similar to those in Laulentia and South China. The peak values of the SPICE vary significantly between regions. The Nevada data (Saltzman et al., 2000) in particular show peak values considerably higher in section than in the other regions. Saltzman et al. (2000) noted that these discrepancies in onset and peak value of the SPICE could be attributed to uncertainties in biostratigraphy. It should also be noted that the successions in these different regions differ significantly in stratigraphical thickness, and the techniques used to measure or sample sections have not been consistent in all regions. The discrepancies in onset and peak value interval of the SPICE seem to be resulted from uncertainties in biostratigraphical resolution and inconsistent sampling technique.

The occurrence pattern of SPICE in the Machari Formation can compare with those in other localities in terms of sea level variation. Peng et al. (2004) reported that the base of the $G$ reticulatus Zone coincides with the initial stages of a transgressive event. Transgression coinciding with the lower part of the $G$. reticulatus Zone is followed by a highstand phase and then a shallowing that is expressed in South China and Laurentia; the eustatic sea level fall is represented in Laurentia as the Sauk Il-Sauk III hiatus (Saltzman et al., 2004). In Scandinavia the onset of deepening is suggested to be coincided with the approximate base of the SPICE (Ahlberg et al., 2009). In the Machari Formation the base of the $G$. reticulatus Zone corresponds to transgressive phase close to maximum flooding surface and is followed by a sea level highstand and then a shallowing event which is in turn followed by transgression. Apparently the $\delta^{13} \mathrm{C}$ variation of SPICE event does not show parallel behavior with sea level curve in the Machari 
Formation. The anoxic condition prior to the SPICE event is thought to be the main cause of the SPICE event in the Machari Formation and the stratigraphic distribution pattern of the SPICE resembles that of from South China in terms of peak shape (Saltzman et al., 2004).

\section{Conclusions}

The Machari Formation, which was interpreted to have been deposited on middle to outer carbonate ramp, was reported to be Middle to Late Cambrian in age. Three cycles of systems tract consists of the Machari Formation; each cycle consists of TST followed by HST. The HST might have been followed by FSST and SB, and LST; however, no distinctive facies change was observed. The lowermost part of the Machari Formation corresponds to the TST which is thought to have been deposited on the siliciclastic substrate, the Sambangsan Formation. The TST is composed of deepening upward sequence showing increased occurrence of laminated and shale facies until the MFS. The MFS is interpreted to occur mostly in the laminated facies. Above the MFS is the HST which is composed of shallowing-upward sequence. The FSST and LST are speculative as the formation shows little variation in lithology with base level change.

The SPICE in the Machari Formation begins with the FAD of trilobite $G$ reticulatus and ends with the FAD of trilobite Irvingella. The $\delta^{13} \mathrm{C}$ values in the SPICE interval in the Machari Formation ranges from 0.6 to $4.4 \%$ and the SPICE is found in approximately $120 \mathrm{~m}$ thick sequence. The SPICE corresponds to the sequence stratigraphic interval which consists of HST to TST. The SPICE in the Machari Formation is thought to be caused by the anoxic condition during which organic matter was buried beneath the sea floor and darkly laminated marl to shale facies were deposited. Burial of organic mater as darkly laminated marl to shale facies is interpreted to have formed the ocean enriched in ${ }^{13} \mathrm{C}$ and the carbonate deposits were high in the $\delta^{13} \mathrm{C}$ values which formed the SPICE. The
SPICE in the Machari Formation suggests that SPICE event might be a global event during the Late Cambrian, which can be used as a good correlation tool for the Late Cambrian strata which show poor biostratigraphic control. Furthermore, the distribution pattern of SPICE in the Machari Formation shows similar to that of South China, suggesting that the Yeongweol Group is similar to South China in terms of paleoenvironment.

\section{Acknowledgments}

This study was financially supported by research fund of the Chungnam National University in 2008. Authors thank to undergraduate students in sedimentology laboratory of the Chungnam National University who assisted field and laboratory work. Authors thank to reviewers including Kim, J.Y. and Kim, J.H., and anonymous reviewer for critical review to improve the manuscript.

\section{References}

Ahlberg, P., Axheimer, N., Babcock, L.E., Eriksson, M.E., Schmitz, B., and Terfelt, F., 2009, Cambrian highresoultion biostratigraphy and carbon isotope chemostratigraphy in Scania, Sweden: First record of the SPICE and DICE excursions in Scandinavia. Lethaia, 42, 2-16.

Catuneau, O., 2006, Principles of sequence stratigraphy. Elsevier, Amsterdam, $375 \mathrm{p}$.

Choi, D.K., 1998, The Yongweol Group (Cambrian-Ordovician) redefined: A proposal for the stratigraphic nomenclature of the Choson Supergroup. Geosciences Journal, 2, 220-234.

Choi, S.J. and Woo, K.S., 1993, Depositional environment of the ordovician yeongheung formation near Machari area, Yeongweol, Kangweondo, Korea. Journal of Geological Society of Korea, 29, 375-386.

Choi, Y.S. and Lee, Y.I., 2000, Space-time-dissociated differential sedimentation and its relationship with the rate of relative sea-level change: The Lower Ordovician Mungok Formation, Korea. Proceeding of 7th Korean Society of Petroleum Geology Symposium, 14-30.

Chung, G.S. and Land, L.S., 1997, Dolomitization of the periplatform carbonate slope deposit, the Machari Formation (Middle to Late Cambrian), Korea. Carbonates and Evaporites, 12, 163-176. 
Chung, G.S. and Lee, E.K., 2002, Depositional environment of the Cambrian Machari Formation in the Yeongweol Area, Gangweon Province, Korea. Journal of the Korean Earth Science Society, 23, 72-86.

Duxbury, A.B. and Duxbury, A.C., 1996, Fundamentals of oceanography. Wm. C. Brown Publishers, Boston, USA, $308 \mathrm{p}$.

Elrick, M., Read, J.F., and Coruh, C., 1991, Short-term paleoclimatic fluctuations expressed in lower Mississippian ramp-slope deposits, southwestern Montana. Geology, 19, 799-802.

Elrick, M. and Hinnov, L.A., 2007, Millennial-scale paleoclimate cycles recorded in widespread Palaeozoic deeper water rhythmites of North America. Palaeogeograhy, Palaeoclimatology, Palaeoecology, 243, 348-372.

Geological Investigation Corps of Taebaegsan Region, 1962, Geological map of Taebaegsan region. Geological Society of Korea, 46 p.

Gill, B.C., Lyons, T.W., Young, S.A., Kump, L.R., Knowll, A.H., and Saltzman, M,R., 2011, Geochemical evidence for widespread euxinia in the Later Cambrian ocean. Nature, 469, 80-83.

Glumac, B. and Mutti, L.E., 2007, Late Cambrian (Steptoean) sedimentation and responses to sea-level change along the northeastern Laurentian margin: Insights from carbon isotope stratigraphy. Geological Society of America Bulletin, 119, 623-636.

Glumac, B. and Walker, K.R., 2000, Carbonate deposition and sequence stratigraphy of the terminal Cambrian grand cycle in the southern Appalachians, U.S.A., Journal of Sedimentary Research, 70, 952-963.

Guo, Q, Strauss, H., Liu, C., Zhao, Y., Yang, X., Peng, J., and Yang, H., 2010, A negative carbon isotope excursion defines the boundary from Cambrian Series 2 to Cambrian Series 3 on the Yangtze Platform, South China. Palaeogeography, Palaeoclimatology, Palaeoecology, 285, 143-151.

Kim, J.C. and Lee, Y.I., 1996, Marine diagenesis of Lower Ordovician carbonate sediments (Dumugol formation), Korea: Cementation in a calcite sea. Sedimentary Geology, 105, 241-257.

Kim, J.Y., Seo, Y.S., and Park, S.I., 1992, Trace fossils from the Yeongheung Formation, Yeongweol, Korea. Journal of Korean Earth Science Society, 13, 313-326.

Kim, J.Y., Kim, T.J., and Jin, Y.P., 2003, Graptolite biostratigraphy of the Mungok Formation (Early Ordovician) in the Hwabyung area, Yeongwol, Korea. Journal of Korean Earth Science Society, 24, 668-683.

Kump, L.R. and Arthur, M.A., 1999, Interpreting carbonisotope excursions: Carbonates and organic matter. Chemical Geology, 161, 181-198.

Lee, J.G., 1995, Late Cambrian trilobites from the Machari Formation, Yeongweol, Korea. Ph.D. Dissertation, Seoul
National University, Seoul, Korea. 418 p.

Lubeseder, S., Redfern, J., and Boutib, L., 2009, Mixed siliciclastic-carbonate shelf sedimentation-Lower Devonian sequences of the SW Anti-Atlas, Morocco. Sedimentary Geology, 215, 13-32.

Paik, I.S., Woo, K.S., and Chung, G.S., 1991, Stratigraphic, sedimentologic and paleontologic investigation of the Paleozoic sedimentary environments of the Lower Ordovician Mungok Formation in the vicinity of Yeongweol. Journal of Geological Society of Korea, 27, 357-370.

Peng, S., Babcock, L.E., Robison, R.A., Lin, H., Rees, M.N., and Saltzman, M.R., 2004, Global Standard Stratotype-section and Point (GSSP) of the Furongian Series and Paibian Stage (Cambrian). Lethaia, 37, 365379.

Reinemund, J.A., 1957, Coalfield of the Republic of Korea, geology of Machari coalfied, pt 2. United States Government Printing Office, Washington, D.C., Geological Survey Bulletin, 1041-C, 47 p.

Saltzman, M.R., Cowan, C.A., Runkel, A.C., Runnegar, B., Stewart, M.C., and Palmer, A.R. 2004, The Late Cambrian SPICE $\left(\delta^{13} \mathrm{C}\right)$ event and the SAUK II-SAUK III regression: New evidence from Laurentian basins in Utah, and Newfoundland. Jouranl of Sedimentary Research, 74, 366-377.

Saltzman, M.R., Ripperdan, R.L., Brasier, M.D., Lohmann, K.C., Robison, R.A., Chang, W.T., Peng, S. Ergaliev, E.K., and Runnegar, B., 2000, A global carbon isotope excursion (SPICE) during the Late Cambrian: Relation to trilobite extinctions, organic-matter burial and sea level. Palaeogeography, Palaeoclimatology, Palaeoecology, 162, 211-223.

Seguret, M., Moussine-Pouchkine, A., Gabaglia, G.R., and Bouchette, F., 2001, Storm deposits and storm-generated coarse carbonate breccias on a pelagic outer shelf (South-East Basin, France). Sedimentology, 48, 231-254.

Woo, K.S. and Moore, C.H., 1996, Burial dolomitization and dedolomitization of the Late Cambrian Wagok Formation, Yeongweol, Korea. Carbonates and Evaporites, 11, 104-112.

Yoo, C.M. and Lee, Y.I., 1997, Depositional cyclicity of the Middle Ordovician Yeongheung Formation, Korea. Carbonates and Evaporites, 12, 192-203.

Zhu, M.Y, Zhang, J.M., Li, G.X., and Yang, A.H., 2004, Evolution of $\mathrm{C}$ isotopes in the Cambrian of China: Implications for Cambrian subdivision and trilobite mass extinctions. Geobios, 37, 287-301.

Manuscript received: August 12, 2011

Revised manuscript received: August 24, 2011 Manuscript accepted: August 29, 2011 